\title{
Biochemical Constituents and Nutritive Evaluation of Some Less Known Wild Edible Plants from Senapati District, Manipur, India
}

\author{
Sanjita C. KONSAM ${ }^{1}$, Kangjam T. DEVI ${ }^{1}$, Jekendra S. SALAM ${ }^{2 *}$, \\ Potshangbam K. SINGH ${ }^{1}$ \\ Manipur University, Centre of Advanced Studies in Life Sciences, Imphal-795003, Manipur, India \\ ${ }^{2}$ Central Agricultural University, College of Agriculture, Imphal,Manipur, India; jekendrasalam@rediffmail.com ("correspondingauthor)
}

\begin{abstract}
Ten lesser known wild edible plants (WEPs) from Senapati District, Manipur, were analyzed for their proximate composition and mineral content. The study revealed that different WEPs have crude fat content that ranged between $0.41-21.5 \%$, total sugar was found to be between $2.00-59.00 \%$, total soluble protein between $1.40-8.0 \%$ and total amino acids between $1.50-5.25 \mathrm{mg} / 100 \mathrm{~g}$ respectively, whereas the highest and the lowest crude protein contents were recorded in H. macrocarpa $(27.56 \%)$ and S. suaveolens (4.37\%) respectively. Among the micronutrients, the highest amounts of $\mathrm{Fe}, \mathrm{Mn}, \mathrm{Zn}, \mathrm{Cu}$ and $\mathrm{Co}$ were recorded in C. hirsuta $(155.50 \mathrm{mg} / 100 \mathrm{~g})$, E. acuminata $(105.50 \mathrm{mg} / 100 \mathrm{~g})$, S. suaveolens $(76.50 \mathrm{mg} / 100 \mathrm{~g}$ in $\mathrm{Zn}$ and $24.0 \mathrm{mg} / 100 \mathrm{~g}$ in Cu) and $R$. ellipticum $(3.0 \mathrm{mg} / 100 \mathrm{~g})$, while the lowest amounts were recorded in E. phaseoloides $(61.50 \mathrm{mg} / 100 \mathrm{~g})$, O. indicum $(1 \mathrm{mg} / 100 \mathrm{~g})$, E. acuminate $(17.50 \mathrm{mg} / 100 \mathrm{~g})$ and C. montana (0.5 $\mathrm{mg} / 100 \mathrm{~g}$ ) respectively. Higher amounts of $\mathrm{Ca}$ and $\mathrm{Mg}$ were observed in all the plants studied, ranging from 458 to $765 \mathrm{mg} / 100 \mathrm{~g}$ in Ca and 148.50 to $995.0 \mathrm{mg} / 100 \mathrm{~g}$ in $\mathrm{Mg}$. E. lineolatum indicated the highest amount of Ca by containing $765.0 \mathrm{mg} / 100 \mathrm{~g}$, while $A$. ciliata recorded the highest value of $\mathrm{Mg}$ by containing $995.0 \mathrm{mg} / 100 \mathrm{~g}$. The nutritive values of the ten WEPs were found to be comparable or even higher than the conventional vegetables, with respect to proteins and minerals, especially for $\mathrm{Ca}, \mathrm{Mg}, \mathrm{Fe}, \mathrm{Mn}$ and $\mathrm{Zn}$ respectively.
\end{abstract}

Keywords: biochemical, nutritive, Senapati district, traditional, wild edible plants

\section{Introduction}

There is a very close association between wild plants and the life of human civilization since time immemorial. People of different countries, different sections, localities and places have their own unique preparations and methods of using them and these have been handed down from generation to generation. The quality of a food depends upon the presence of relative concentration of various nutrients such as proteins, fats, carbohydrates, vitamins and minerals. Carbohydrates, fats and proteins are considered as proximate principles and form the major portion of the diet, while minerals play an important role in the regulation of the metabolic activity in the body (Gopalan et al., 2004; Pfoze et al., 2012).

As major portion of our diet is obtained from plants, understanding their nutritive values is an important aspect. Nutrition plays a critical role in wellness, by not only providing essential nutrients, but also promoting good health and preventing diseases (Ogle et al., 2003). These wild edible plants are collected by the local tribes not only as famine or hunger food, but also have been recognized to have potential to meet household food and income security (Mahapatra $e t$ al., 2012).

\section{Materials and Methods}

Ethno botanical surveys with respect to ethnic food plants were conducted during December 2009 - June 2012 in the Senapati District, Manipur. Ten lesser known wild edible plants (WEPs) were short listed as these are widely consumed by the local tribes for their good taste. Depending on the information provided by the local populations, different edible portions of the plants were collected, washed and dried in the shade. They were grounded and sieved to a fine powder which would be used for various analyses.

Total sugar, total free amino acid, soluble protein content were estimated following the procedures of Dubois et al. (1951), Yemm and Cocking (1955) and Lowry et al. (1951). Total crude protein, crude fibre and crude lipid were estimated as per the methods described in Chopra and Kanwar (1980). For minerals estimation, plant samples were subjected to wet digestion method of Capar et al. (1978). Ca, $\mathrm{Mg}, \mathrm{Fe}, \mathrm{Co}, \mathrm{Cu}, \mathrm{Zn}$ and $\mathrm{Mn}$ were determined in a Parkin Elmer atomic absorption spectrophotometer, Analyst AA200. Phosphorous was estimated in a spectrophotometer by using Vanado Phosphomolybdate yellow colour method of Gupta (2006). 


\section{Results and Discussion}

Wild food plants are important in many indigenous communities around the world (Biswas and Mohammed, 2011). Wild edible plants play a vital role providing nourishment (Jansen, 2004) and variety in the diet and contribute to health maintenance as functional or medicinal foods (Orech et al., 2007). There are various reports about the use of such wild plants in Manipur (Dipankar, 2013). Analyses of the nutritional content of plants have been done in a number of studies (Dipankar, 2013; Samancioglu, 2016). Data in Table 1 indicates the relatively high crude protein content in almost all the plant samples under study. Different WEPs have crude lipid content ranging from 0.41 to $19.82 \%$. The crude lipid content was higher in the seeds of Oroxylum indicum (19.82\%) and the lowest in the epicarp of Stixix suaveolens $(0.41 \%)$. The total soluble protein varied between $1.40-5.50 \%$, while the highest value was recorded in Acmella ciliata (5.50\%) and the lowest in the leaves of Rhynchotechum ellipticum (1.40\%). The highest and the lowest crude protein content were recorded in Hodgsonia macrocarpa (27.56\%) and S. suaveolens $(4.37 \%)$ respectively. Among the studied plants, a wide variation in total sugar, ranging from 2.5 to $59 \mathrm{mg} / 100 \mathrm{~g}$, was observed, while a fairly uniform distribution of the total free amino acid, ranging from 1.50 to $5.25 \mathrm{mg} / 100 \mathrm{~g}$, was recorded.

Table 2 indicates the mineral composition within the ten plants studied. Among the macro elements, high amounts of $\mathrm{Ca}$ and $\mathrm{Mg}$ were detected in all the plants studied, ranging from 458 to $765 \mathrm{mg} / 100 \mathrm{~g}$ in $\mathrm{Ca}$ and 148.50 to 995.0 $\mathrm{mg} / 100 \mathrm{~g}$ in $\mathrm{Mg}$, respectively. The highest amount of Ca was detected in Elatostema lineolatum $(765.00 \mathrm{mg} / 100 \mathrm{~g})$ and $\mathrm{Mg}$ in Acmella ciliata (995.0 mg/100 g), while the lowest amounts were recorded in Oroxylum indicum $(458.5 \mathrm{mg} / 100$ g) and in the epicarp of $S$. suaveolens $(148.5 \mathrm{mg} / 100 \mathrm{~g})$. Phosphorus content in all the plants was very less and ranged from 10 to $180 \mathrm{mg} / 100 \mathrm{~g}$ only.

Micro-element analysis in the ten plants indicated considerably high amounts of $\mathrm{Fe}, \mathrm{Mn}$ and $\mathrm{Zn}$. Fe content ranged from 61.5 to $155.5 \mathrm{mg} / 100 \mathrm{~g}$, out of which, significantly high amounts of $\mathrm{Fe}$ were recorded in Cardamine hirsuta (155.5 mg/100 g), Rhynchotechum ellipticum (131.0 mg/100 g) and Acmella ciliata (100 $\mathrm{mg} / 100 \mathrm{~g})$. Mn content among the ten plants varied considerably and ranged from $1.0 \mathrm{mg} / 100 \mathrm{~g}$ in the seeds of

Table 1. Proximate composition (\%) of ten wild edible plants collected from Senapati District, Manipur (average of two independent readings)

\begin{tabular}{|c|c|c|c|c|c|c|c|c|c|}
\hline No. & Plant & Local name & Parts used & $\begin{array}{l}\text { Total } \\
\text { sugar }\end{array}$ & $\begin{array}{l}\text { Total } \\
\text { free } \\
\text { amino } \\
\text { acids }\end{array}$ & $\begin{array}{c}\text { Total } \\
\text { soluble } \\
\text { protein }\end{array}$ & $\begin{array}{c}\text { Crude } \\
\text { lipid }\end{array}$ & $\begin{array}{l}\text { Crude } \\
\text { fiber }\end{array}$ & $\begin{array}{l}\text { Crude } \\
\text { protein }\end{array}$ \\
\hline 1 & Acmella ciliata & Manjareng & Whole aerial part & 2.5 & 2.62 & 5.50 & 2.92 & 14.29 & 22.49 \\
\hline 2 & Cardamine hirsuta & Uchi-hangam & Whole aerial part & 6.25 & 3.75 & 4.10 & 5.54 & 10.35 & 22.93 \\
\hline 3 & Cucurma montana & Tekhao-yaikhu & Inflorescence & 5.25 & 1.50 & 3.50 & 1.85 & 8.6 & 5.43 \\
\hline 4 & Elatostema lineolatum & Ching Sougri & Whole aerial part & 2.00 & 5.25 & 5.05 & 2.20 & 15.4 & 24.15 \\
\hline 5 & Entada phaseoloides & Khangkhil & Leaves & 4.25 & 2.62 & 4.50 & 5.02 & 11.33 & 22.51 \\
\hline 6 & Eurya acuminata & Shijou & Leaves & 7.5 & 5.25 & 3.00 & 3.88 & 15.42 & 7.88 \\
\hline 7 & Hodgsonia macrocarpa & Lam-mairel & Cotyledons & 2.50 & 3.00 & 3.75 & 21.5 & 6.25 & 27.56 \\
\hline 8 & Oroxylum indicum & Shamba & Seed & 7.50 & 1.87 & 5.25 & 19.82 & 9.14 & 26.63 \\
\hline 9 & Rhynchotechum ellipticum & Yembum & Leaves & 5.25 & 1.50 & 1.40 & 2.15 & 11.47 & 10.24 \\
\hline \multirow{6}{*}{10} & \multirow{2}{*}{ Stixis suaveolens } & \multirow{2}{*}{ Urirei } & Fruit pulp & 9.75 & 2.25 & 2.65 & 1.20 & 14.63 & 4.38 \\
\hline & & & Epicarp & 59.00 & 4.87 & 5.00 & 0.41 & 9.23 & 7.53 \\
\hline & Mean & & & 10.16 & 3.13 & 3.97 & 6.04 & 11.46 & 16.52 \\
\hline & S.D. & & & 16.38 & 1.44 & 1.27 & 7.40 & 3.10 & 9.28 \\
\hline & S.Em & & & 4.94 & 0.43 & 0.38 & 2.23 & 0.94 & 2.80 \\
\hline & C.V. & & & 161.20 & 45.81 & 31.89 & 122.38 & 27.05 & 56.16 \\
\hline
\end{tabular}

Table 2. Mineral contents (mg/100 g) of ten wild edible plants collected from Senapati District, Manipur (average of two independent readings)

\begin{tabular}{|c|c|c|c|c|c|c|c|c|c|c|c|}
\hline No & Plant & Local name & Parts used & $\mathrm{P}$ & $\mathrm{Ca}$ & $\mathrm{Mg}$ & $\mathrm{Fe}$ & $\mathrm{Mn}$ & $\mathrm{Zn}$ & $\mathrm{Cu}$ & Co \\
\hline 1 & Acmella ciliata & Manjareng & Whole aerial part & 90.0 & 645.0 & 995.0 & 100.0 & 4.5 & 20.0 & 3.0 & 2.5 \\
\hline 2 & Cardamine hirsuta & Uchi-hangam & Whole aerial part & 110.0 & 655.0 & 483.0 & 155.5 & 3.0 & 27.5 & 3.0 & 2.5 \\
\hline 3 & Cucurma montana & Tekhao-yaikhu & Flower and inflorescence & 60.0 & 630.0 & 471.5 & 80.5 & 70.0 & 36.0 & 0.5 & 0.5 \\
\hline 4 & Elatostema lineolatum & Ching Sougri & Whole aerial part & 80.0 & 765.0 & 760.0 & 94.5 & 82.5 & 27.5 & 2.0 & 2.0 \\
\hline 5 & Entada phaseoloides & Khangkhil & Leaves & 30.0 & 555.0 & 208.5 & 61.5 & 10.5 & 18.5 & 4.0 & 2.0 \\
\hline 6 & Eurya acuminata & Shijou & Leaves & 30.0 & 600.0 & 306.0 & 88.0 & 105.5 & 17.5 & 0.50 & 1.0 \\
\hline 7 & Hodgsonia macrocarpa & Lam-mairel & Cotyledons & 160.0 & 555.0 & 277.5 & 66.0 & 2.5 & 30.0 & 2.0 & 1.0 \\
\hline 8 & Oroxylum indicum & Shamba & Seed & 180.0 & 458.5 & 238.5 & 63.0 & 1.0 & 23.5 & 11.0 & 1.5 \\
\hline 9 & Rhynchotechum ellipticum & Yembum & Leaves & 40.0 & 690.0 & 261.0 & 131.0 & 11.0 & 43.5 & 2.5 & 3.0 \\
\hline \multirow[t]{6}{*}{10} & \multirow{6}{*}{ Stixis suaveolens } & \multirow{2}{*}{ Urirei } & Fruit pulp & 40.0 & 487.5 & 187.0 & 66.5 & 2.5 & 76.5 & 1.5 & 1.0 \\
\hline & & & Epicarp & 10.0 & 486.0 & 148.5 & 84.5 & 2.0 & 54.5 & 24.0 & 2.0 \\
\hline & & Mean & & 75.5 & 593.4 & 394.2 & 90.1 & 26.8 & 34.1 & 4.9 & 1.7 \\
\hline & & S.D. & & 55.4 & 95.1 & 266.4 & 29.8 & 39.0 & 18.0 & 7.0 & 0.8 \\
\hline & & S. Em \pm & & 16.7 & 28.7 & 80.3 & 9.0 & 11.8 & 5.4 & 2.1 & 0.2 \\
\hline & & C.V. & & 73.4 & 16.0 & 67.6 & 33.1 & 145.4 & 52.8 & 141.6 & 45.5 \\
\hline
\end{tabular}




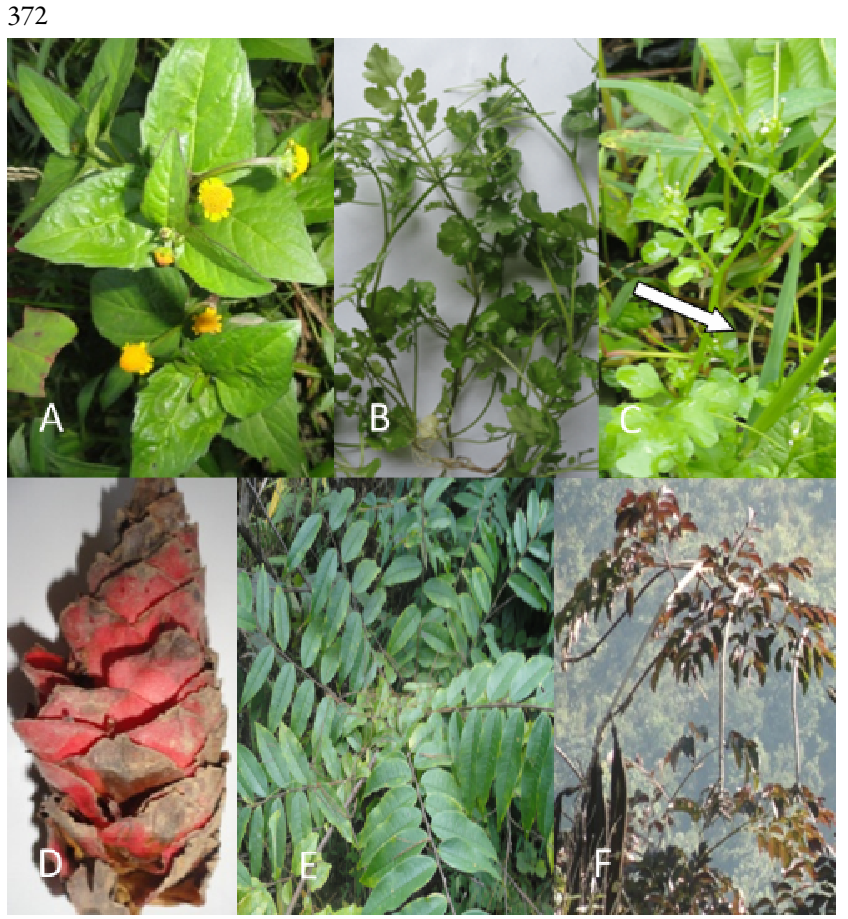

Fig. 1. Photographs of wild edible plants: (A) Acmella ciliata, (B) Cardamine hirsuta, (C) Cardamine hirsuta plant in wild habitat, (D) Inflorescence of Cucurma montana, (E) Eurya acuminata leaves, (F) Oroxylum indicum plant with pods

Oroxylum indicum, to $105.5 \mathrm{mg} / 100 \mathrm{~g}$ in the leaves of Eurya acuminata. Considerably high amounts of $\mathrm{Mn}$ were also recorded in Elatostema lineolatum $(82.5 \mathrm{mg} / 100 \mathrm{~g})$ and Cucurma montana $(70.0 \mathrm{mg} / 100 \mathrm{~g})$. Zn distribution in the ten plants was fairly uniform and ranged from 17.5 to $76.5 \mathrm{mg} / 100 \mathrm{~g}$. Considerably higher amounts of $\mathrm{Zn}$ were recorded in Stixis suaveolens $(76.5 \mathrm{mg} / 100 \mathrm{~g})$ and Rhynchotechum ellipticum ( $43.5 \mathrm{mg} / 100 \mathrm{~g}$ ). $\mathrm{Cu}$ and $\mathrm{Co}$ content, though were lesser in extent than the other micro-elements, thus recorded fairly uniform values, ranging from 0.50 to $24.0 \mathrm{mg} / 100 \mathrm{~g}$ in $\mathrm{Cu}$ and 0.5 to 3.0 $\mathrm{mg} / 100 \mathrm{~g}$ in Co respectively.

\section{Conclusions}

The nutritional value of many traditional leafy vegetables is higher than several known common cultivated vegetables. As vegetables are especially considered main suppliers of vitamins and minerals rather than proteins and energy Acmella ciliata, Cardamine birsuta, Elatostema lineolatumand and Eurya acuminata may be valuable for human diet, as their mineral content with respect to $\mathrm{Ca}, \mathrm{Mg}, \mathrm{Fe} \mathrm{Mn}$ and $\mathrm{Zn}$ far exceeds than the dietary allowances recommended, thus represent potential sources of nutrients.

\section{Acknowledgements}

The authors are grateful to the Dean from College of Agriculture, Central Agricultural University, Iroishemba, for providing laboratory facilities. They are also thankful to the local people and traditional healers of Senapati District for their cooperation during field survey.

\section{References}

Biswas KR, Mohammed Rahmatullah (2011). A survey of nonconventional plants consumed during times of food scarcity in three adjoining villages of Narail and Jessore Districts, Bangladesh. American-Eurasian Journal of Sustainable 5(1):1-5.

Capar SG, Tanner JT, Friedman MH, Boyer KW (1978). Multielement analysis of animal waste and sewage sludge. Environmental Science and Technology 12:785-790.

Chopra SL, Kanwar JS (1980). Analytical agricultural chemistry. Kalyani Publishers, New Delhi pp 337-346.

Dipankar Deb, Abhijit Sarkar, Bhabani Deb Barma, Datta BK, Koushik Majumdar (2013). Wild edible plants and their utilization in traditional recipes of tripura, Northeast India. Advances in Biological Research 7(5):203-211.

Dubois M, Gilles K, Hamilton JK, Rebers PA, Smith F (1951). A calorimetric method for the determination of sugars. Nature pp 167-168.

Gopalan CR, Sastri BV, Balasubramanian SC (2004). Nutritive value of Indian foods. National Institute of Nutrition, Indian Council of Medical Research, Hyderabad 500007, India.

Gupta PK (2006). Soil, plant, water and fertilizer analysis. Agrobios Agro House, Behind Nasraru Cinema Chopsail Road, Jodhpur India, pp 241.

Jansen RWS, Ventor SL, Netschluvhi TR, Heever E, Vorster HJ, de Ronde JA (2004). Role of indigenous leafy vegetables in combating hunger and malnutrition. South African Journal of Botany 70:52-59.

Lowry OH, Resebrough NJ, Farr LA, Randall RJ (1951). Protein measurement with the Folin-Phenol reagent. Journal of Biological Chemistry 193:265-275.

Mahapatra AK, Mishra S, Basak UC, Panda PC (2012). Nutrient analysis of some selected wild edible fruits of deciduous forests of India: an explorative study towards non-conventional bionutrition. Advance Journal of Food Science and Technology 4(1):15-21.

Ogle BM, Tuyet HT, Duyet HN, Dung NNX (2003). Food, feed or medicine: the multiple functions of edible wild plants in Vietnam. Economic Botany 57(1):103-117.

Orech FO, Aagard-Hansen J, Friis H (2007). Ethno ecology of traditional leafy vegetables of the Luo people of Bondo district, Western Kenya. Journal of Food Science and Nutrition 58:522530.

Pfoze NL, Kumar Y, Sheikh N, Myrboh B (2012). Assessment of local dependency on selected wild edible plants and fruits from Senapati district, Manipur, Northeast India. Applied Ethnobotanical Research 10:357-367.

Samancioglu A, Sat IG, Yidirim E, Ercisli S, Jurikova T, Mlcek J (2016). Total phenolic and vitamin $C$ content and antiradical activity evaluation of traditionally consumed wild edible vegetables from Turkey. Indian Journal of Traditional Knowledge 15(2):208-213.

Yemme EW, Cocking EC (1955). The determination of amino acids with ninhydrin. Analyst 80:209-213. 